\title{
Occurrence of geohelminths in the soil of public squares in Rio Branco, Acre State, Brazilian Western Amazon
}

\section{Ocorrência de geohelmintos em solo de praças públicas em Rio Branco, estado do Acre, Amazônia Brasileira}

\author{
Jefté Teixeira da Silva'; Keli Pinheiro Menezes²; Leonardo Augusto Kohara Melchior ${ }^{3}$; \\ Vânia Lúcia Brandão Nunes ${ }^{4}$; Andreia Fernandes Brilhante ${ }^{1}$ (D) \\ ${ }^{1}$ Universidade Federal do Acre, Centro de Ciências da Saúde e do Desporto, Rio Branco - AC, Brazil \\ ${ }^{2}$ Centro Universitário Unimeta, Rio Branco - AC, Brazil \\ ${ }^{3}$ Universidade Federal do Acre, Centro de Ciências Biológicas e da Natureza, Rio Branco - AC, Brazil \\ ${ }^{4}$ Universidade Anhanguera, Laboratório de Parasitologia Humana, Campo Grande - MS, Brazil.
}

\begin{abstract}
Soil contamination by dog and cat feces can become a public health problem due to the transmission of various etiologic agents that cause zoonoses. This study aimed to verify the occurrence of geohelminths in the soil of some public square areas of the municipality of Rio Branco, Acre State, Western Brazilian Amazon. Five public squares were selected, and soil samples collection was performed from April 2014 to March 2015. The samples were processed by using the Baermann-Moraes and centrifugal-flotation methods. Geohelminths positivity was of $25 \%$ for Toxocara spp., $6.6 \%$ for the Ancylostomatoidea Superfamily and 1.6 for Trichuris spp.. Measures should be implemented to prevent the free access of animals to these places, as well as deworming of stray dogs and cats and the implementation of population control and policies for such animals.
\end{abstract}

Keywords: Soil contamination. Public squares. Toxocara. Ancylostomatoidea.

\section{RESUMO}

A contaminação do solo por fezes de cães e gatos pode se tornar um problema de saúde pública devido à transmissão de vários agentes etiológicos que causam zoonoses. Este estudo objetivou verificar a ocorrência de geohelmintos no solo de praças públicas do município de Rio Branco, estado do Acre, Brasil. Cinco praças públicas foram selecionadas e amostras de solo foram colhidas entre abril de 2014 e março de 2015. As amostras foram processadas pelos métodos de Baermann-Moraes e centrífugo-flutuação. A positividade observada para geohelmintos foi de 25\% para Toxocara spp., 6,6\% para a Superfamília Ancylostomatoidea e 1,6\% para Trichuris spp.. Medidas devem ser implementadas para prevenir a livre circulação de animais nestes locais, bem como a desverminação de cães e gatos de rua e a implementação de políticas de adoção e controle populacional de cães e gatos.

Palavras-chave: Contaminação do solo. Praças públicas. Toxocara. Ancylostomatoidea.

Correspondence to:

Andreia Fernandes Brilhante

Universidade Federal do Acre, Centro de Ciências da Saúde e

do Desporto

BR 364, Km 04, Distrito Industrial

CEP: 69920-900, Rio Branco - AC, Brazil

e-mail: afb.brilhante@gmail.com

Received: November 01, 2019

Approved: April 07, 2020

How to cite: Silva JT, Menezes KP, Melchior LAK, Nunes VLB, Brilhante AF. Occurrence of geohelminths in the soil of public squares in Rio Branco, Acre State, Brazilian Western Amazon. Braz J Vet Res Anim Sci. 2020;57(2):e163783. https://doi.org/10.11606/issn.16784456.bjvras.2020.163783

The construction of public squares and recreational environments has increased due to governmental initiatives, aiming to promote better living conditions for the population. However, while they contribute to health promotion, public squares and recreational environments may pose serious health risks to their users, often becoming sources that spread various infectious diseases, if these locations are not properly cared for (Araújo et al., 1999; Santos et al., 2006).

These public environments are widely frequented by domestic pets such as dogs and cats, which end up excreting 
their parasite-contaminated feces in these environments (Figueiredo et al., 2012; Maciel et al., 2016). Parasitic forms found in animal feces may remain free, living in the environment until they come into contact with a host, where they may subsequently develop. In addition, the parasites can develop in the soil until its infective stage, and then may have contact with the host and/or penetrate the host's body, thus establishing parasitosis (Nunes et al., 2000).

As it is a public health problem, the parasitological evaluation of soil in public places is particularly important for verifying the risks to which the population is being submitted. Thus, the objective of the present study is to analyze the occurrence of geohelminths in the soil of public square areas of the Rio Branco municipality, Acre State, Western Amazon.

This descriptive and exploratory study was carried out from Regional V in Rio Branco, with five public square environments chosen for convenience and located in the following neighborhoods: Novo Horizonte, Mascarenha de Moraes, Vila Betel, Esperança III and Bela Vista. Sample collections were carried out in the mornings, from April 2014 to March 2015. Monthly collections were performed from each square during a 12-month period, totaling 60 samples. Regarding the characteristics of the squares, all were frequently used by the local population, had few trees, except for Mascarenhas de Morais, which was more shaded due to the presence of more trees.

Collections were done by using disposable plastic spoons, with superficial and deep scraping of approximately $5 \mathrm{~cm}$ of the soil. These samples were processed using the Baermann-Moraes method for larvae research, and by Faust for eggs and cysts, with some modifications made by Nunes et al. (2000).

Table 1 - Frequency (\%) and number (n) of positive samples by parasitic forms in soil of public recreation areas, Rio Branco, Acre State, Western Brazilian Amazon, 2014-2015

\begin{tabular}{lc}
\hline \multicolumn{1}{c}{ Parasitic forms } & Frequency (n) \\
\hline Nematode Larvae & $40.0(24)$ \\
Toxocara spp. egg & $25.0(15)$ \\
Ancylostomatoidea Superfamily egg & $6.6(4)$ \\
Trichuris spp. egg & $1.6(1)$ \\
\hline
\end{tabular}

Of a total of 60 analyzed samples from the five areas, $40 \%$ were positive for nematode larvae and $33.2 \%$ positive for helminth eggs (Table 1). The most common parasites observed were Toxocara spp. and those of the Ancylostomatoidea superfamily. Similar results were also observed in other studies like the one of sand from public squares of Espírito Santo state (Maciel et al., 2016), in the peridomicile of a fishing area of Mato Grosso do Sul state (Brilhante et al., 2013), or even in the children's play areas in Rio Grande do Sul state (Mascarenhas et al., 2016).

Different from our results, higher percentages of contamination were observed in public areas in other regions of Brazil, such as in the countryside of São Paulo state where Coelho et al. (2011) observed $87.9 \%$ of canine feces positive for Ancylostoma spp. and on soil samples and animal feces of some beaches in Salvador, Bahia state (Santos et al., 2006) that observed $78.7 \%$ of positivity for Ancylostoma spp. and $45.9 \%$ for Toxocara spp. In our study, we could not analyze fecal samples because we only found three samples, far from the collection points, in which two were positive for hookworm eggs.

Considering our results of the five squares altogether, we confirmed the presence of geohelminths in all months of the year (Table 2). Due to the fact that sample size was small for the studied period, it was not possible to observe seasonality. However, in the rainy period, which runs from October to March, at Rio Branco city, the average positivity of the squares was 3.5, while in the dry period, from April to September, the average was 2.17. Similar results were observed in Santos (Rocha et al., 2011) and Uruguaiana (Figueiredo et al., 2012), where the highest frequency of geohelminths occurred during the rainy months.

Our results corroborate the study of Ferreira et al. (2018) who also observed high percentage of contamination by Toxocara spp. and hookworm eggs, as well as nematode larvae in recreational areas of Rio Branco, which were different from the ones we analyzed. These results draw attention to the fact that many public places of Rio Branco city may be contaminated with these parasites.

During sample collections, the presence of dogs and cats was noted, which can justify the contamination of these environments, as the squares did not have fences or

Table 2 - Positivity of geohelminths in soil samples of public areas of Rio Branco, Acre State, Western Brazilian Amazon, during the months of April 2014 to March 2015

\begin{tabular}{|c|c|c|c|c|c|c|c|c|c|c|c|c|}
\hline Areas & Apr & May & Jun & Jul & Aug & Sep & Oct & Nov & Dec & Jan & Feb & Mar \\
\hline Novo horizonte & + & - & - & - & - & + & + & + & + & + & + & + \\
\hline Mascarenhas de Morais & + & + & + & - & + & + & - & - & + & + & + & + \\
\hline Conjunto Esperança III & - & - & - & + & + & - & + & + & + & - & - & + \\
\hline Vila Betel & - & - & - & - & + & + & + & - & - & - & + & + \\
\hline Bela Vista & - & - & + & - & - & + & + & - & - & + & + & + \\
\hline
\end{tabular}


protection preventing the entry of these animals. It is also important to point out that the occurrence of contamination by Toxocara spp. becomes even more favorable, due to the fact that dogs are born infected, so these animals must be dewormed in the second week of life to prevent the spread of these parasites (Gennari, 2015).

The studied public places of Rio Branco city are contaminated with zoonotic parasites. Thus, parasitological assessment of soils in public areas is essential to verify the risks to which the population is being exposed, as well as to help while implementing preventive measures, such as

\section{References}

Araújo FR, Crocci AJ, Rodrigues RGC, Avalhaes JS, Miyoshi MI, Salgado FP, Silva MA, Pereira ML. Contaminação de praças públicas de Campo Grande, Mato Grosso do Sul, Brasil, por ovos de Toxocara e Ancylostoma em fezes de cães. Rev Soc Bras Med Trop. 1999;32(5):581-3. http://dx.doi. org/10.1590/S0037-86821999000500017. PMid:10881094.

Brilhante AF, Nunes VLB, Dorval MEC. Presence of Toxocara spp. and hookworms in peridomiciliary areas of a fishing community in the Mid-west region of Brazil. Braz J Vet Res Anim Sci. 2013;50(1):71-3. http://dx.doi. org/10.11606/issn.2318-3659.v50i1p71-73.

Coelho WMD, Amarante AFT, Apolinário JC, Coelho NMD, Bresciani KDS. Occurrence of Ancylostoma in dogs, cats and public places from Andradina city, São Paulo state, Brazil. Rev Inst Med Trop. 2011;53(4):181-4. http://dx.doi. org/10.1590/S0036-46652011000400001. PMid:21915459.

Ferreira ISR, Nery Júnior MJ, Moraes MHS, Maggi LE, Brilhante AF, Sabino KC. Frequência de geo-helmintos em áreas recreativas da cidade de Rio Branco, Estado do Acre, Brasil. South American J Basic Edu Tech Technol. 2018;5(1):68-77.

Figueiredo MIO, Wendt EW, Santos HT, Moreira CM. Levantamento sazonal de parasitos em caixas de areia nas escolas municipais de educação infantil em Uruguaiana, RS, Brasil. Rev Patol Trop. 2012;41(1):36-46.

Gennari SM. Principais helmintos intestinais em cães no Brasil. Boletim Bayer Vet [Internet]. 2015 [cited 2020 Jan 25];2(8):1-8. Available from: https://s3-sa-east-1. installing barriers to prevent the free access of animals, deworming stray animals, and implementing animal population control policies.

\section{Conflict of Interest}

The authors declare no conflict of interest.

\section{Ethics Statement}

This article does not contain any studies with human participants or animals.

amazonaws.com/vetsmart-contents/Documents/DC/Bayer/ Boletim_Principais_Helmintos_Intestinais_Caes_Brasil.pdf

Maciel JS, Esteves RG, Souza MAA. Prevalência de helmintos em areias de praças públicas do município de São Mateus, Espírito Santo, Brasil. Nat Online. 2016;14:15-22.

Mascarenhas JP, Silva D, Silva DA. Presença de parasitos no solo das áreas de recreação em escolas de educação infantil. J Nurs Heal. 2016;6(1):76-82.

Nunes CM, Pena FC, Negrelli GB, Anjo CGS, Nakano $\mathrm{MM}$, Stobbe NS. Ocorrência de larva migrans na areia de áreas de lazer das escolas municipais de ensino infantil, Araçatuba, SP, Brasil. Rev Saude Publica. 2000;34(6):6568. http://dx.doi.org/10.1590/S0034-89102000000600015. PMid:11175613.

Rocha S, Pinto RMF, Floriano AP, Teixeira LH, Bassili B, Martinez A, Costa SOP, Caseiro MM. Environmental analyses of the parasitic profile found in the sandy soil from the Santos municipality beaches, SP, Brazil. Rev Inst Med Trop. 2011;53(5):277-81. http://dx.doi.org/10.1590/ S0036-46652011000500007. PMid:22012454.

Santos NM, Silva VMG, Thé TS, Santos AB, Souza TP. Contaminação das praias por parasitos caninos de importância zoonótica na orla da parte alta da cidade de Salvador-BA. Rev Ciênc Méd Biol. 2006;5(1):40-7. http:// dx.doi.org/10.9771/cmbio.v5i1.4579.

Financial Support: None. 